\title{
Var Leifur heppni lánsamur eða frækinn?
}

Í grein í tímaritinu Sögu veltir Gunnar Karlsson (2014:87-97) sagnfræðingur pví fyrir sér hvers vegna Leifur Eiríksson var kallaður heppinn. Niðurstaða hans er pessi: „Leifur hlýtur að hafa verið kallaður inn heppni vegna pess að hann pótti færa öðru fólki höpp.“ (Gunnar Karlsson 2014:97). Gunnari pykir nefnilega ekki líklegt að hann hafi hlotið sérstakt happ af pví að bjarga mönnum úr sjávarháska eins og segir í textunum sem um hann fjalla: 1) Eiríks sögu rauða, 2) Ólafs sögu Tryggvasonarí Heimskringlu, 3) Kristni sögu og 4) Grænlendinga sögu. Frásagnirnar af Leifi heppna eru tilfærðar hér úr fimm heimildum:

1 a) „Lætr Leifr í haf ok er lengi úti ok hitti á lond pau, er hann vissi áđr enga ván til. Váru par hveitiakrar sjálfsánir ok vínviðr vaxinn. Par váru pau tré, er mǫsurr heita, ok hơfðu peir af pessu ollu nǫkkur merki, sum tré svá mikil, at í hús váru loggd. Leifr fann menn á skipflaki ok flutti heim með sér. Sýndi hann í pví ina mestu stórmennsku ok drengskap, sem mǫrgu @ðru, er hann kom kristni á landit, ok var jafnan síðan kallaðr Leifr inn heppni." (Eiríks saga rauða 1935:211-212).

1 b) „Leifr lét í haf pegar hann var búinn. Leif velkði lengi úti, ok hitti hann á lọnd pau er hann vissi áðr øngva ván í. Váru par hveitiakrar sjálfsánir ok vínviðr vaxinn; par váru ok pau tré er mǫsurr heita, ok họfðu peir af gllu pessu nọkkur merki. Leifr < fann menn á skipflaki 
ok> flutti heim með sér ok fekk ollum vist um vetrinn. Sýndi hann í pví hina mestu stórmennsku ok gæzku af sér. Hann kom kristni á landit (+ ok hann bjargaði mǫnnunum 557). Var hann <síðan> kallaðr Leifr hinn heppni." (Eiríks saga rauða 1985:415).

2) „Óláfr konungr sendi ok pat sama vár Leif Eiríksson til Grœenlands at boða par kristni, ok fór hann pat sumar til Grœnlands. Hann tók í hafi skipsogn peira manna, er bá váru ófœrir ok lágu á skipsflaki, ok pá fann hann Vínland it góða ok kom um sumarit til Grœnlands ok hafði pannug með sér prest ok kennimenn ok fór til vistar í Brattahlíð til Eiríks, fǫður síns. Menn kǫlluðu hann síðan Leif inn heppna. En Eiríkr, faðir hans, sagði, at pat var samskulda, er Leifr hafði borgit skipsogn manna, ok pat, er hann hafði flutt skémanninn til Grœnlands. Pat var prestrinn." (Heimskringla I 1941:347-348).

3) „Pá fann Leifr Vínland it góða. Hann fann ok menn á skipflaki í hafi. Pví var hann kallaðr Leifr inn heppni." (Kristni saga 2003:30).

4) „Sigla nú síðan í haf, ok gaf peim vel byri, par til er peir sá Grœnland ok fjoll undir jǫklum. Pá tók einn maðr til máls ok mælti við Leif: „Hví stýrir pú svá mjok undir veðr skipinu?" Leifr svarar: „Ek hygg at stjórn minni, en pó enn at fleira, eða hvat sjái pér til tíðenda?" Peir kváðusk ekki sjá , pat er tíðendum sætti. „Ek veit eigi,“ segir Leifr, „hvárt ek sé skip eða sker.“ Nú sjá peir ok kváðu sker vera. Hann sá pví framar en peir, at hann sá menn í skerinu. „Nú vil ek, at vér beitim undir veðrit,“" segir Leifr, „svá at vér náim til peira, ef menn eru purftugir at ná várum fundi, ok er nauðsyn á at duga peim; en með pví, at peir sé eigi friðmenn, pá eigu vér allan kost undir oss, en peir ekki undir sér." Nú sœkja peir undir skerit ok lægðu segl sitt, kọstuðu akkeri ok skutu litlum báti oðrum, er peir hǫfðu haft með sér. [...] „Nú vil ek," segir Leifr, „bjóða yðr ollum á mitt skip ok fémunum peim, er skipit má við taka." Peir págu pann kost ok sigldu síðan til Eiríksfjarðar með peim farmi, par til er peir kómu til Brattahlíðar; báru farminn af skipi. Síðan bauð Leifr Póri til vistar með sér ok Guðríði, konu hans, ok primr mǫnnum oðrum, en fekk vistir oðrum hásetum, bæði Póris ok sínum félogum. 
Leifr tók fimmtán menn ór skerinu. Hann var síðan kallaðr Leifr inn heppni." (Gronlendinga saga 1935:253254).

5) „Leifr hinn hepni, var [...] pví svá kallaðr, at hann barg skipshöfn í miðju hafi." (ONP).

Hér er auknefni Leifs beinlínis tengt björgunarafreki hans en ekki pví að hann fann Vínland eða kom kristni á Grænland.

Gunnar (2014:91) segir að heppinn sé einkum sá sem fær meiri og betri hlut í lífinu en hæfileikar eins og styrkur, vit og hófsemi geti skýrt. Pví megi segja að pað hafi verið öfugmæli að Leifur hafi verið heppinn. Niðurstaða Gunnars (2014:97) er sem sagt sú að heppinn hafi getað merkt 'happaveitull' en ekki aðeins 'happsamur'.

Pessi niðurstaða Gunnars er ekki að öllu leyti fullnægjandi. Orðið happ merkir 'pað sem maður fær fyrir heppni' (Íslensk orðabók 2002:533), p.e. pað sem einhverjum hlotnast sjálfum persónulega en er ekki hægt að veita öðrum. Á sama hátt er heppinn sá 'sem hefur heppnina með sér' (Íslensk orðabók 2002:571). Dæmin sem tekin eru til vitnisburðar í grein Gunnars skera ekki úr um merkinguna, sérstaklega ekki dæmin úr kveðskap.

Hvað sem líður peim dæmum úr fornritum sem Gunnar tekur til athugunar og hann telur styðja mál sitt, ætla ég að líta til grannmáls okkar færeysku til pess að styðja annan skilning á orðinu heppinn en við höfum í nútímamáli. Orðið heppin merkir par, auk pess að pýða 'eydnusamur', p.e. lánsamur, 'kvikur, kringur, fermur, snarráðin”, eins og í dæminu „hann má vera (heppin) ið skal gera tílíkt roysni“ (Føroysk orðabók 1998:451). Orðið roysni er skilgreint í sömu færeysku orðabókinni pannig: „djørv gerð gjørd undir truplum umstøðum, roysnisbragd, bragd, roysnisverk, kappabragd“. I færeyskdanskri orðabók (Jacobsen og Matras 1961:157) er orðið heppin pýtt sem 'rask og snar, behændig'. Á sama hátt er færeyska roysni pýtt 'manddomsværk, (stor) bedrift, vovestykke, styrkeprøve' í sömu orðabók. Í aukabindi pessarar orðabókar er orðið heppibragd tilfært og pýtt sem 'heldig bedrift, snarrådig gerning' (Jacobsen og Matras 1974). Mér pykir líklegt að Leifur hafi ekki síst hlotið viðurnefni sitt vegna pess björgunarafreks sem hann vann sem sýnir snarræði hans og hreysti. Í Grænlendinga sögu (1935:252) er sagt um Leif: „Leifr var mikill maðr ok sterkr, manna skoruligastr at sjá, [...]." Pessi ummæli styðja fremur en hitt að hann hafi verið heppinn í hinni færeysku merkingu. 
Í Grettis sögu kemur orðið heppinn fyrir í samhengi sem mér finnst einkar athyglisvert út frá pví sem að framan segir. Par segir frá pví að Grettir ásamt kaupmönnum gátu ekki tekið eld par sem peir tóku land í Noregi vegna illviðris en sáu að eldur mikill kom upp öðru megin pess sunds er peir voru pá við komnir. Síðan segir:

„En er skipverjar Grettis sá eldinn, tọluðu peir til, at sá væri heppinn, er honum gæti nát, ok efuðusk í, hvárt peir leysa skyldi skipit, en pat sýndisk ollum eigi hættulaust. Pá hǫfðu peir umtal mikit, hvárt nọkurr maðr myndi svá vel fœrr, at næði eldinum. Grettir gaf sér fátt at ok segir, at verit myndi hafa peir menn, er pat myndi ekki trauðat hafa [p.e. vílað fyrir sér]. Kaupmenn sogðu, at sér væri eigi at borgnara, hvat er verit hafði, ef pá væri til einskis at taka, - „eða treystir pú pér, Grettir?" sogðu peir, ,"pví at pú ert nú mestr atgørvismaðr af íslenzkum mọnnum kallaðr, en pú veizt nú gǫrla, hvat oss liggr á.“ Grettir svarar: „Eigi lízk mér mikit prekvirki at ná eldinum [...]" (Grettis saga Ásmundarsonar 1936:129).

Parna sýnist mér einboðið að heppinn eigi við prekvirkið sem skipverjar Grettis telja að purfi til að ná eldinum.

Mín niðurstaða er að orðið heppinn í norrænu hafi getað merkt 'frækinn, hraustur, vel fær, snarráður' eða pvílíkt, auk pess að merkja 'lánsamur' og að fyrri merkingin eigi við viðurnefni Leifs Eiríkssonar.

\section{Heimildir}

Eiríks saga rauða. 1935. Útg. Matthías Pórðarson. Íslenzk fornrit IV. Reykjavík: Hið íslenzka fornritafélag.

Eiríks saga rauða. 1985. (Texti Skálholtsbókar AM 557 4to) Útg. Ólafur Halldórsson. Íslenzk fornrit IV. Viðauki. Reykjavík: Hið íslenska fornritafélag. Føroysk orðabók. 1998. Ritstjórn: Jóhan Hendrik W. Poulsen, Marjun Simonsen, Jógvan í Lon Jacobsen, Anfinnur Johansen, Zakaris Svabo Hansen. Tórshavn: Føroya Fróðskaparfelag.

Grettis saga Ásmundarsonar. 1936. Útg. Guðni Jónsson. Íslenzk fornrit VII. Reykjavík: Hið íslenzka fornritafélag.

Groenlendinga saga. 1935. Útg. Matthías Pórðarson. Íslenzk fornrit IV. Reykjavík: Hið íslenzka fornritafélag.

Gunnar Karlsson. 2014. Hvers vegna var Leifur Eiríksson kallaður heppinn? Saga LII:2:87-97.

Heimskringla I = Snorri Sturluson. 1941. Heimskringla I. Útg. Bjarni Aðalbjarnarson. Íslenzk fornrit XXVI. Reykjavík: Hið íslenzka fornritafélag. 
Íslensk orðabók. 2002. (3. útgáfa, aukin og endurbætt.) Ritstjóri: Mörður Árnason. Reykjavík: Edda útgáfa hf.

Jacobsen, M.A. og Chr. Matras. 1961. Føroysk-donsk orðabók. (2. útgáva, nógv broytt og økt.) Tórshavn: Føroya Fróðskaparfelag.

Jacobsen, M.A. og Chr. Matras. 1974. Føroysk-donsk orðabók. Eykabind. Latið úr hondum hevur Jóhan Hendrik W. Poulsen. Tórshavn: Føroya Fróðskaparfelag.

Kristni saga. 2003. Útg. Sigurgeir Steingrímsson. Íslenzk fornrit XV:2. Reykjavík: Hið íslenska fornritafélag.

ONP = Ordbog over det norrøne prosasprog Online onp.ku.dk. Bein slóð: http:// onpweb.nfi.sc.ku.dk/webart/h/he/33327255700cartpnfr.htm (sótt 2018).

Svavar Sigmundsson

Rannsóknarprófessor emeritus

svavar@hi.is 
